DOI https://doi.org/10.30525/978-9934-26-109-1-23

\title{
РОЗВИТОК МЕТОДІВ ОЦІНКИ \\ НАПРУЖЕНО-ДЕФОРМОВАНОГО СТАНУ АРМОВАНОГО ЖОРСТКОГО ДОРОЖНЬОГО ОДЯГУ
}

\author{
Гамеляк І. П. \\ доктор технічних наук, професор, \\ завідувач кафедри аеропортів \\ Національний транспортний університет
}

\begin{abstract}
Цибульський В. М.
старший викладач кафедри опору матеріалів та машинознавства Національний транспортний університет
\end{abstract}

Харченко А. М.

кандидат технічних наук, дочент, доцент кафедри транспортного будівництва та управління майном Національний транспортний університет м. Київ, Украӥна

Розвиток сучасних матеріалів та техніки, що використовуються при будівництві автомобільних доріг напряму пов'язаний зі створенням нових конструктивних рішень [1], які би відповідали зростаючим вимогам надійності, міцності і економічності даних споруд. У світі все ширше використовуються конструкції дорожнього одягу основною особливістю яких $\epsilon$ неоднорідність, багатошаровість та поєднання матеріалів 3 різними фізико-механічними характеристиками, які входять в клас кусково-неоднорідних. Такі системи проектують для забезпечення міцності дорожнього одягу при постійному збільшені інтенсивності руху та граничного навантаження.

Визначення складових напружено-деформованого стану таких багатошарових систем $є$ складним завданням механіки деформованого твердого тіла. Певною мірою це завдання може бути вирішено на основі розробки універсальних теоретичних моделей, для яких число i порядок розв'язувальних рівнянь не залежить від ступеня неоднорідності конструктивних елементів дорожнього одягу, але які дають можливість визначити складові напружено-деформованого стану в шарах конструкції [2]. 
Розрахунок шаруватих композитних конструкцій з використанням рівнянь тривимірної теорії пружності розглядається в науковій праці Я.М. Григоренка, А.Т. Василенка, Н.Д. Панкратової [3]. При цьому отримано рішення рівнянь просторової лінійної теорії пружності неоднорідних анізотропних шаруватих оболонок. Авторами розглянуто прямокутні в плані ортотропні шаруваті конструкції при деяких граничних умовах, що допускають поділ перемінних.

Найбільш широке розповсюдження отримав підхід на основі двовимірних теорій шаруватих систем викладений в роботах С.А. Амбарцумяна [4]. Згідно з цією теорією вводяться гіпотези про розподіл поперечних дотичних напружень по товщині пакету, які в межах кожного шару характеризуються певним законом зміни та модулем поперечного зсуву.

Для побудови двовимірних рівнянь теорії кусково-неоднорідних шаруватих систем існує два напрями застосування гіпотез розподілу напружень, які викладені в роботі Е.І. Григолюка, Ф.А. Когана [5].

В першому підході для виведення рівняння застосовуються кінематичні гіпотези для кожного окремого шару, порядок рівнянь при цьому залежить від числа шарів. Система рівнянь багатошарових пластин 3 довільною кількістю прошарків була побудована В.В. Болотіним [6], що дає змогу з високою ступеню точності описати загальний напружено-деформований стан армованих шаруватих конструкцій.

Для теорії другого напрямку вводяться загальні гіпотези, що неперервно описують шарувату систему по товщині. Надалі цей напрямок отримує широкий розвиток [7] зважаючи на його переваги при реалізації - це незалежність числа і порядку дозвільних рівнянь від кількості шарів, що має велике значення для конструкцій 3 композиційних матеріалів.

Ця перевага відкриває можливість до об'єднання теорій шаруватих систем 3 найбільш ефективним чисельним методом механіки деформованого твердого тіла - методом скінчених елементів для розрахунку неоднорідних конструкцій.

\section{Література:}

1. Цибульський В.М. Сучасні матеріали для армобетонних конструкцій автодорожніх мостів. ХІІ Всеукраӥнська заочна науковопрактична конференція, Освіта і наука в Україні: иляхи розвитку та напрямки взаємодї: тези доповідей. м. Харків, 2020. С. 16-17. 
2. Пискунов В.Г. Проблема построения моделей физикомеханических процессов в слоистых конструктивних системах. Механика неоднородных структур. Львов, 1987. С. 211-212.

3. Василенко А.Т., Григоренко Я.М., Панкратова Н.Д. Напряженное состояние трансверсально-изотропных неоднородных толстостенных сферических оболочек. Докл. АН СРСР. Механика твердого тела, 1976. № 1. С. 59-66.

4. Амбарцумян С.А. Теория анизотропных пластин. М.: Наука. 1987. C. 360.

5. Григолюк Э.И., Коган Ф.А. Современное состояние теории многослойных оболочек. Прикл. механика,1972. 8, № 6. С. 3-17.

6. Болотин В.В. К теории слоистых пластин. Изв. АН СРСР. Отдние техн. наук Механіка и машиностроение. 1963. № 3. С. 65-72.

7. Пискунов В.Г. Об одном варианте неклассической теориимногослойных пологих оболочек и пластин. Прикладная механика. 1979. 15, № 11. С. 76-81.

DOI https://doi.org/10.30525/978-9934-26-109-1-24

\title{
TECTONIC FORMATION OF BIOCLIMATIC HIGH-RISE BUILDINGS
}

\author{
Krivenko O. V. \\ Candidate of Technical Sciences, \\ Associate Professor at the Department of Architectural Constructions \\ Kyiv National University of Construction and Architecture
}

\author{
Bukina Yu. O. \\ Senior Lecturer at the Department \\ of Language Communication and Training \\ Kyiv National University of Construction and Architecture \\ Kyiv, Ukraine
}

The problem statement. In search for ways to develop mega cities in the balance between artificial and natural environment is becoming a general trend of our time [1, p. 8]. In modern cities, the development of high-rise buildings to improve their adaptive characteristics, the possibility 